\title{
Case for diagnosis. Palate perforation due to cocaine use*
}

\author{
Graciela Fernández Blanco ${ }^{1}$ \\ Mariana Martínez ${ }^{1}$
}

DOI: http:/ / dx.doi.org/10.1590/abd1806-4841.20177232

\author{
Maria Cecilia Madeo ${ }^{1}$ \\ María Emilia Vázquez ${ }^{1}$
}

\section{CASE REPORT}

A 42-year-old woman with a hard palate with mucosal and bone destruction, with nasal regurgitation and rhinolalia, was treated with oral antibiotics with no result. Background: cocaine by inhalation ( $2 \mathrm{~g} /$ day) for 15 months, and stopped consuming three years ago because of its buconasal fistula. Physical examination of the oral cavity presents a palate perforation, oval of 4 by $3 \mathrm{~cm}$, net limits, asymptomatic (Figure 1). Saddle nose, widening of the tip and destruction of the nasal septum (Figure 2).

\section{Routine exams were normal.}

A biopsy specimen from the nasal mucosa displayed ulceration and granulomatous inflammation with suppurative pattern suggestive of a benign inflammatory process. Computed axial tomography of the craniofacial mass in the coronal section shows absence of the nasal septum, turbinates, and internal wall of the right maxillary sinus with subtotal destruction of the hard palate (Figure3). An acrylic and removable silicone prosthesis the patient was referred for treatment of the addiction (Figure 4).

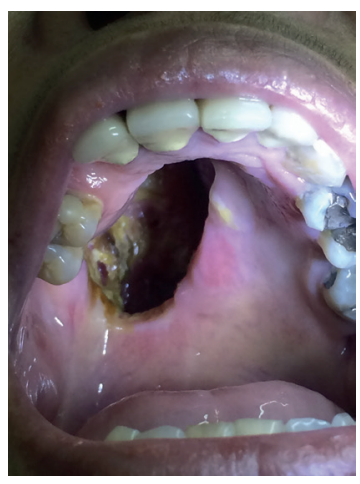

Figure 1: Large ulcer in the hard palate
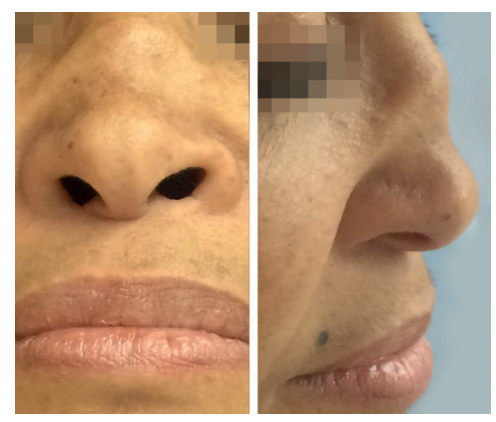

Figure 2: Saddle nose with widened nasal tip

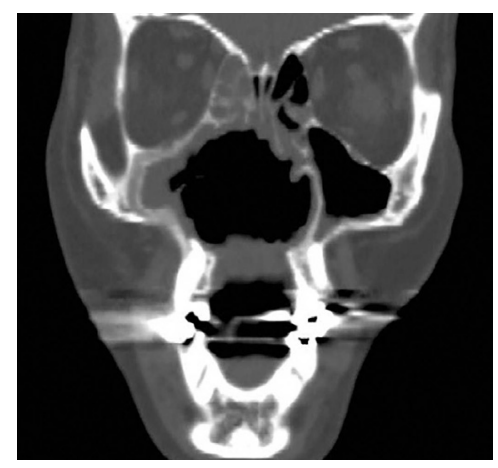

Figure 3: CT (coronal section): absence of nasal septum, turbinates, and internal wall of the right maxillary sinus; partial destruction of the hard palate
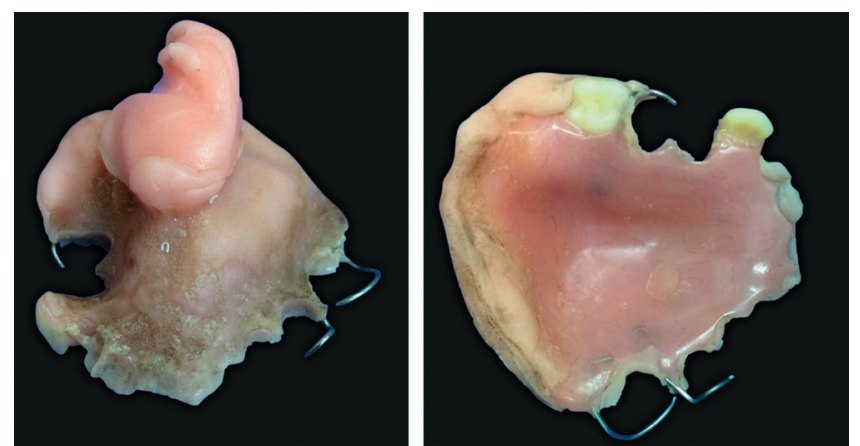

FIGURE 4: Silicone and acrilic palate prosthesis

\section{Received on 20.04.2017}

Approved by the Advisory Board and accepted for publication on 19.05.2017.

* Work performed at the Departament of Dermatology of Hospital General de Agudos Enrique Tornú, Buenos Aires, Argentina.

Financial support: none.

Conflict of interest: none.

1 Departament of Dermatology of Hospital General de Agudos Enrique Tornú - Buenos Aires, Argentina.

(O2017 by Anais Brasileiros de Dermatologia 


\section{DISCUSSION}

Cocaine is a crystalline alkaloid extracted from the leaves of the coca plant (Erytroxylum coca) that contains psychoactive properties by direct sympathomimetic action. The cocaine-induced damage is multifactorial; multifactorial; it causes a vasoconstricting a vasoconstricting effect that produces ischemia and an anesthetic effect on the mucosa, while chronic inhalation produces necrosis and infection of osteocartilaginous tissues. As a result of chronic inhalation (nasal use), it causes rhinitis, epistaxis, perforation of the nasal septum, destruction of the lateral wall of the nose and perforation of the palate with oronasal communication. The diagnosis of cocaine-induced midline destructive lesions (CIMDL) requires two of the following signs: 1) Perforation of the nasal septum; 2) Destruction of the nasal lateral wall; and 3) involvement or perforation of the hard palate. These lesions should be differentiated from Wegener's granulomatosis, NK T-lymphoma, actinomycosis, and tertiary syphilis. Nasal septum perforation in cocaine users is asymptomatic and tolerated but the oronasal fistula produces rhinolalia and passage of liquids and solids to the nose. Women are more susceptible to perforate the palate and to develop a greater inflammatory impairment of the connective, carilaginous and bone tissues than man. It is essential for the patient to definitively abandon cocaine use in order to consider the reconstruction. $\square$

\begin{abstract}
We report a 42-year-old cocaine addicted female patient referred for evaluation of hard palate ulceration resulting in oro-sinus communication with difficulties in swallowing and phonation, an rhino-sinusitis. Acrylic and removable silicone prosthesis was prescribed to relieve severe functional disorders. It is essential that the patient permanently abandons cocaine use to perform surgical reconstruction.
\end{abstract}

Keywords: Cleft palate; Cocaine; Oral fistula; Palatal obturators; Palate; Palate, hard

\section{REFERENCES}

1. D`Addino JL, Pigni MM, Venegas S. Lesión de paladar duro por uso crónico de cocaína. Reporte de un caso. Avan Biomed. 2014;3:98-101.

2. Trimarchi M, Sykopetrites V, Bussi M. Management of a cocaine induced palatal perforation with a nasal septal button. Ear Nose Throat J. 2016;95:E36-8.

3. Rachapalli SM, Kiely PD. Cocaine induced midline destructive lesions mimicking Ent- limited Wegener's granulomatosis. Scand J Rheumatol. 2008;37:477-80

4. Colletti G, Autelitano L, Chiapasco M, Biglioli F, Giovanditto $\mathrm{F}$, Mandalà M, et al. Comprehensive surgical management of cocaine induced midline destructive lesions. J Oral Maxillofac Surg. 2014;72:1395.e1-10.

5. Padilla-Rosas M, Jimenez-Santos Cl, García-González CL. Palatine perforation induced by cocaine. Med Oral Patol Oral Cir Bucal. 2006;11:E239-42.
6. Lypka MA, Urata MM. Images in clinical medicine cocaine induced palatal perforation. N Engl J Med. 2007;357:1956.

7. Seyer BA, Grist W, Muller S. Aggressive destructive midfacial lesion from cocaine abuse. Oral Surg Oral Med Oral Pathol Oral Radiol Endod. 2002:94:465-70.

8. Bonner Osorio CB, Castillo López IY. Lesión destructiva de la línea media inducida por cocaína. Comunicación de un caso. An Oral Mex. 2009; 54: 32-5

9. Plaza G, Espinoza A, Ferrando J, Pinedo F. Granulomatosis de Wegener y lesiones destructivas de la línea media facial por cocaína: diagnostico diferencial. Med Clin 2009; 133: 237-8.

MAILING ADDRESS:

Dra. Graciela Fernández Blanco.

Servicio de Dermatología del Hospital E. Tornú

Dirección: Combatientes de Malvinas 3002, CABA

Buenos Aires, Argentina

E-mail:consuderm@gmail.com

How to cite this article: Blanco GF, Madeo MC, Martínez M. Case for diagnosis. Palate perforation due to cocaine use. An Bras Dermatol. 2017;92(6): 877-8. 